DOI: $10.1515 /$ ausp-2015-0002

\title{
Intercultural Reflections on Translating Petófi onto Serbian Language
}

\author{
Ferenc NÉMETH \\ University of Novi Sad (Serbia) \\ Teacher's Academy in Hungarian Language, Subotica \\ ferencnemet@yahoo.co.uk
}

\begin{abstract}
Only six years subsequent to Petőfi's disappearance, i.e. his death, in 1855 the Petőfi reception took on in Serbian literature, when Jovan Jovanović Zmaj translated the poem A csárda romjai (Razorena čarda [The Ruins of the Inn]). From that point on, Petőfi became part of Serbian literature as well: famous and popular, to such an extent that there was hardly a Serbian poet who would not engage in translating at least one of Petőfi's poems. Sava Babić, who made an account of the Petőfi translations published between 1855 and 1980, listed as many as 658 entries in his bibliography. Translating Petőfi's poems, according to literary historians, "proved an outstanding bridge between the lives of the two neighbouring nations" (Nagy 1994). ${ }^{1}$ These poems substituted for what Serbian literature lacked-the Serbian folk epic poem. Towards the end of the $19^{\text {th }}$ century, the reception of Petoffi's poetry in Serbian literature virtually bloomed into a cult, namely because his poems of patriotic and social themes as well as his revolutionary poetry quite complied and were even consonant with the increasingly aggressive patriotism of the so-called New Serbian Youth (Nova omladina). In the second half of the $20^{\text {th }}$ century, the receptive attitude towards his poetry waned significantly. The study looks into the characteristics and effects of the translations of Petőfi's poetry from its 'literary transfer,' its receptive situation, up to the intensification of its popularity and folklorization. In fact, it analyzes the literary/cultural transfer which fulfilled certain needs and conjunctures, but which was surprisingly integrated into the Serbian literary tradition of the late $19^{\text {th }}$ and early $20^{\text {th }}$ century.
\end{abstract}

Keywords: Sándor Petőfi, literary translation, Serbian literary reception, cult, literary transfer

According to István Lőkös, in the Serbian literature of the mid-19 ${ }^{\text {th }}$ century, there were three Serbian poets from Hungary who "within a short period, raised Serbian literature onto a high level, even of European standards. (...) All three of them were raised on Hungarian culture and educated in Hungarian schools;

1 Quotations from Hungarian specialist literature were translated by the author. 
all three of them lived within contemporary Hungarian literature” (Lőkös 2004). These poets were Jovan Jovanović Zmaj, Đura Jakšić and Laza Kostić. ${ }^{2}$ Each of them enriched their own oeuvre as well as the whole of Serbian literature with the reception of one of the most prominent figures of Hungarian poetry. Among them Zmaj, the leading figure in building Serbian-Hungarian relations, undertook translating and popularizing Petőfi's, Arany's and Madách's works.

Subsequent to the 1848-49 Revolution, it understandably took quite some time for the Serbian anti-Hungarian actions to wane and for the general attitude and tone of Serbian-Hungarian relations to improve. According to István Póth, among the Serbs "the Hungarian influence (...) was primarily noticeable in cultural and literary life. (...) This (...) was specifically represented (...) in the field of literature through a rapidly created and so-to-speak general Petőfi cult” (Póth 1972, 388).

However, in the literary sense, "the tone (...) towards the Hungarians becomes that of a friendly kind in the oeuvre of Jovan Jovanović Zmaj” (Lőkös 2004). In István Lőkös's words, Zmaj "first became a recipient of Petőfi's poetry as a translator, and the translatorial impulses were those that gave Zmaj's original poems the Petőfi-esque atmosphere and character." (idem) This left a hallmark of Petőfi's poems on Zmaj's poetry, which points at a strong literary transfer.

Only six years subsequent to Petőfi's disappearance, i.e. his death, in 1855 the Petőfi reception took on in Serbian literature, when Jovan Jovanović Zmaj translated the poem A csárda romjai (Razorena čarda [The Ruins of the Inn]) (Babić 1985, 26; Petefi 1855, 148-152). As István Fried put it, "both the gesture and the choice of poems can be seen as a symbolic act: opposition to the Bach era, using Petőfi's name and the idea of his love of freedom” (Fried 1987, 319).

To quote Sava Babić, "from then on, Petőfi became an integral part of Serbian literature as well" (Babić 2009, 99). He became renowned and popular in Serbian literature, so that there was hardly a Serbian poet who did not engage in translating at least one of Petőfi's poems (idem, 139). The following Serbian periodicals and magazines had his poetry translated and published continually: Serbski Letopis, Neven, Sedmica, Danica, Komarac, Javor, Sloga, Matica, Polaženik, Vienac, Srpska sloga, Sloboda etc. (Babić 1985, 351-378). As the popularity of Petôfi's poetry grew, so did the number of its translators. Thus, apart from Zmaj, poems by Petőfi were translated by Ivan Maršovski, Milan Andrić, Josip Eugen Tomić, Mita R. Stojković, Josip Jukić, Ivan Vončina, Đura Strajić, Đorđe Srdić, Blagoje Brančić, Vidoje Žeravica, Ivan M. Popović, Laza Kostić, Radovan Košutić, Milutin Jakšić and others. Later there were Bogdan Čiplić, Mladen Leskovac, Josip Velebit, Enver Čolaković, Veljko Petrović, Danilo Kiš, Sava Babić and Marija Cindori.

2 Đura Jakšić was Petőfi's great admirer, and although he fought in the opposing Serbian army, "he stayed Petőfi's follower with fervent soul throughout the confrontations" (Németh 2014, 223). Their correspondence shows that he even translated Petőfi's poems. Laza Kostić was another aficionado and translator of Petőfi's poetry. 
Sava Babić, who made an account of the Petőfi translations published between 1855 and 1980, listed as many as 658 entries in his bibliography (idem).

\section{Translation as 'substitution' in the recipient literature}

Studying Serbian literary translations of the late $19^{\text {th }}$ century, Dušan Ivanić came to the conclusion that, on the one hand, the translated literary texts had a fertilizing effect in contemporary Serbian magazines and periodicals, while, on the other hand, they substituted for what Serbian literature lacked at that time - the Serbian folk epic poem (Ivanić 1988, 195). This is the reason why the works of Hungarian poets_-primarily Petőfi's and Arany's-were so attractive to Serbian translators (idem, 196). This was a significant recognition since it boosted literary/intercultural transfer, which had a stopgap role in Serbian literature. Ivanić points to another important detail in connection with Petőfi's unflagging popularity: his poems of patriotic and social themes as well as his revolutionary poetry quite complied and were even consonant with the increasingly aggressive patriotism of the so-called New Serbian Youth (Nova omladina) (idem, 197). This circumstance also sped up the reception of Petőfi's poetry and heightened the work of translators.

Jovan Jovanović Zmaj, the most distinguished Petőfi translator of the late $19^{\text {th }}$ century, completed the translation of János vitéz (John the Valiant) as early as 1858, but due to political reasons it could not be published before 1860 (idem, 29, 62).

According to Imre Bori, "When Zmaj translated Petőfi’s János vitéz [...] into Serbian, he actually filled the gap of the Serbian folk epic, in other words, he brought in what Serbian literature had lacked” (Bori 1970, 73).

\section{Folklorization of Petófi translations}

On the occasion of Zmaj's death in 1904, the magazine Bácska, regarding his poetic translations, found it important to underline that

[...] the popularity of the poem beginning with the line Falu végén kurta kocsma [There is an Inn at the End of the Village]... well proves the fidelity of his translations. It can be said that this poem is equally well known in the Serbian world as in the Hungarian one. In the southern fringe regions in Serbia and in all the corners of the Balkans inhabited by Serbs, people know it by heart, while only few would know that it is not an original poem written in Serbian. (Anonymous 1904) 
This is a fine example of total assimilation into the recipient literary context, i.e. of folklorization of Petőfi translations.

What also speaks for Petőfi's popularity among the Serbs, and goes along with the fact of folklorization, is the claim by Vladislava Polit that "Petôfi's poems were often recited during Serbian feasts as if they had originally been written in Serbian, like Az órült [The Madman], Három fiú [The Three Boys]; what is more, some of the poems were even made into songs and were sung at merry occasions, like Falu végén kurta kocsma..., Ambrus gazda [Master Ambrus], Ezrivel terem fán a meggy [Cherry Grows by the Thousand]..." (Polit 1912, 31-32).

According to Veljko Petrović, "nowhere was Petőfi so well received and embraced, in a word-adopted, as here, particularly among the Serbs. His name was even pronounced in a particularly soft homely way, 'Petefi', since his good reputation reached the farthest corners of the country, and because his translated poems made their way to all levels of society; they were sung for a long time and are still sung to certain well-known melodies" (Petrović 1958, 580). Having talked like this, Petrović refers not only to the Petőfi cult created among the Serbian people, but also to the folklorization of Petôfi's poems in Serbian literature.

To the Serbian reading public, the lyrical Petőfi emerged much earlier than the revolutionary Petófi. The latter was recognized only just after World War I, when one of his popular revolutionary poems entitled Az itélet [Strašni sud - The Verdict], often recited at workers' gatherings, was published on the front page of the paper Radnička straža of its $1^{\text {st }}$ May 1919 issue (David 1977, 185). This poem, being appropriate and topical, and due to its ideological motives, was often recited during the National Liberation War (WWII) at certain partisan meetings. In addition, in 1944 it was even printed in a publication in Lika (Zbornik građe za kulturno-umjetničku propagandu [Collection of Materials for Cultural and Political Propaganda]) (idem). After 1946, for a briefer period, serving the general political atmosphere, the communist ideology continued to promote poems by the revolutionary Petőfi (Babić 1985, 372; Petefi 1946). All this speaks for the scope of the popularity of Petőfi's poems.

However, as early as between the two World Wars, interest in Petőfi's poetry almost completely ceased-with the exception of five-six translations (idem, 371372). Only after World War II, in 1946, did the publication of his selected poems (Izabrane pesme) bring back Petőfi's verse into Serbian literature (idem; Petefi 1946).

\section{From reception to cult: creators of the Petófi cult in Serbia}

Vladislava Polit, who conducted detailed research on Petőfi's popularity and cult in Serbian literature as early as 1912, found that the poet had greatly influenced the Serbs and that he "was an idol to the youth, who saw him as a genuine 
leader who unified all the ideals of national freedom. [...] This was what made Petőfi immortal not only among the Hungarians but also [...] among the Serbs" (Polit 1912, 15). In her words, "already in the 1850s, Petôfi won the affection of Serbian readers, and from then on, his cult kept spreading. [...] Certain Serbian poets drew enthusiasm from Petőfi's poetry, and so did the reading public who keenly read the greatest Hungarian lyricist whenever they had the opportunity to indulge in such pleasure" (idem, 17). Vladislava Polit highlights three translators of Petőfi as the creators of his cult in Serbia: Jovan Jovanović Zmaj (idem, 17-19), Blagoje Brančić (idem, 29-34) and Milan L. Popović (idem, 41-44).

Of Zmaj's translations, Polit holds the opinion that "they are superbly successful, so much that they still remain Petőfi's poems, they are only clad into the Serbian language" (idem, 19). In addition, she risks the statement that by means of the popular Petőfi translations Zmaj is "more popular among the Serbian readers than with several of his own original poems” (idem, 20).

Regarding the Novi Sad born translator Blagoje Brančić, she states that "he was the initiator of the Petôfi cult among the Serbs"3 since "he not only translated Petőfi's poetry but he also looked at him from a scientific angle, and being a teacher at the Novi Sad Grammar School he inspired his students to read Petôfi, so the generations of students graduating from the Grammar School at Brančićs time saw Petőfi as an icon, wrote abundantly about him, and translated his poems. That period can boldly be called the age of Petőfi among the Serbs, since there was actually a genuine infatuation with him" (idem, 34). In his student days, Brančić wrote the poem Petófi szobra elótt [In front of Petófi's statue], which was published in a contemporary almanac (idem, 31). How Brančić "looked at Petőfi from a scientific angle" can be seen through the following examples.

In 1900, in the Matica Srpska Yearbook he published an extensive treatise on Petőfi, which he formulated in cult-like rhetoric:

Petőfi's services to the nation politically fit the war-time merits of an ingenious army general. [...] Poets can be best compared to stars. [...] One star shines less brightly, lights only its nearest vicinity and extinguishes sooner; another star burns more luminously knowing no boundaries. Thus, among the poets some also illuminate a narrower circle, while some reach out to the whole world. [...] They shine for the entire humanity and exist infinitely, since their ideas too, which they have composed in verse, are eternal. [...] Petőfi as a first-rate poet will live ceaselessly, and so will the undying ideas of his verse. What he sang in his poetry touches the whole world; the entire world has recognized it and will treasure it. He undeniably deserves the words of a Serbian poet: 'Happy is one who lives eternally, he was worth being born.' (Brančić qtd. in Polit 1912, 38-39).

3 According to Vladislava Polit, Brančić translated about 150-200 poems by Petőfi. 
Referring to the lawyer from Pančevo, later a newspaper editor and Petófi translator Milan L. Popović (1883-?), Vladislava Polit underlines that "he was Petőfi's ardent admirer as early as in his schooldays. He even translated some of Petőfi's poems and read them out at literature club meetings," while his first Petőfi translations came out in Ženski Svet, Brankovo Kolo and Bosanska Vila magazines (idem, 42). As she put it, "Popović's greatest accomplishment was that he was the first to introduce Petôfi's poetry to the Serbs living in Serbia" (idem). In 1904, Popović published a discourse on Petőfi in Delo magazine, Belgrade, and "since then attention to Petőfi has risen increasingly" (idem). In this discourse, Popović gave the following appraisal:

What I most admire and am in awe of are his remarkable odes which have not yet been exceeded in excellence or beauty. Petőfi reaches the climax of his art in them. With his love poetry he gained popularity, while his patriotic and sublime odes indebted his nation and brought him immortality. [...] His patriotism is unsurpassed, zealous. He sacrificed everything he had, his love and himself, everything in the world, and fought with exhilaration in the battlefield to die heroically for the nation and to return as their apostle praising the divine, sacred doctrine of liberty, fraternity and equality. (Popović qtd. in Polit 1912, idem, 43-44)

András Dávid is apparently right when he says that "Petőfi's poetry and revolutionary figure have been consistently popular among South Slav nations" (David 1977, 185).

\section{Conclusions}

The Serbian reception of Petőfi made its start in 1855, owing to the translation by Jovan Jovanović Zmaj Razorena čarda (A csárda romjai - Ruins of the tavern), a poem by Petőfi. From that time, the foundations of the Petőfi cult in Serbian literature were laid predominantly by Jovan Jovanović Zmaj, Đura Jakšić and Laza Kostić, who were later joined by a number of poets-translators in the $20^{\text {th }}$ century, like Bogdan Čiplić, Mladen Leskovac, Veljko Petrović, Danilo Kiš, Sava Babić and others. The secret of Petőfi's popularity in Serbia was that his patriotic poems with a highly social message, as well as his revolutionary poetry, particularly in the 1880s, suited and even struck the same chord as the growing patriotism of the New Serbian Youth (Nova omladina).

Later Petőfi's popularity was changing: the revolutionary Petőfi was discovered by the Serbs just after the First World War, in 1919, and also again in 1944, 
and in 1946 too, as the communist ideology some time used the revolutionary Petôfi poems. Later, the $120^{\text {th }}$ anniversary of his death (1969) and his $150^{\text {th }}$ birth anniversary (1973) were good opportunities for publishing several volumes of his poems.

\section{Works cited}

Anonymous. 1904. Zmaj-Jovánovics János. [Jovan Jovanović Zmaj.] Bácska, 17 June, 5 .

Babić, Sava. 1985. Kako smo prevodili Petefija. [How We Translated Petőfi.] Istorija i poetika prevoda. Novi Sad: Matica srpska.

Babić, Sava. 2009. Mađarska civilizacija. Uvod u Hungarologiju. [Hungarian Civilization.]. 2nd ed. Senta: Nacionalni savet mađarske nacionalne manjine Zavod za kulturu vojvođanskih Mađara.

Bori Imre. 1970. Magyar-délszláv irodalmi kapcsolatok. [Hungarian and South Slavic Literary Relations.] Novi Sad: Tartományi Tankönyvkiadó Intézet.

David Andraš. 1977. Mostovi uzajamnosti. [Bridges of reciprocity.] $O$ jugoslovensko-mađarskim kulturnim i književnim vezama. Novi Sad: Radnički univerzitet "Radivoj Ćirpanov"

Fried István. 1987. Szerb-magyar múvelődési kapcsolatok (1849-1867). [SerbianHungarian Cultural Relations (1849-1867)] In Szerbek és magyarok a Duna mentén. Tanulmányok a szerb-magyar kapcsolatok köréből 1848-1867 [Serbs and Hungarians along the Danube. Studies on Serbian-Hungarian Cultural Relations 1848-1867], ed. Fried István, 307-331. II., Budapest: Akadémiai Kiadó.

Ivanić, Dušan. 1988. Zabavno-poučna periodika srpskog realizma. [Entertaining and educational periodicals of Serbian realism.] Novi Sad: Matica srpskaInstitut za književnost i umetnost.

Lőkös István. 2004. A szerb irodalom magyarságképéról. [Hungarian Image of the Serbian Literature] Hitel, May: 90-101.

http://epa.oszk.hu/01300/01343/00029/dunataj.html (Accessed on 15 March 2014)

Nagy Magdolna. 1994. „Tiszta vizú forrás”. Kedden, Kiskőrösön leleplezték Jovan Jovanović Zmajnak, Petőfi egyik legjelesebb szerbhorvát fordítójának mellszobrát. ["Stream with Clean Water." On Tuesday at Kiskőrös the Bust of Jovan Jovanović Zmaj, One of the Most Notable Serbo-Croatian Translators of Petőfi, Was Unveiled.] Magyar Szó, 16 June.

Németh Ferenc. 2014. Arany, Jókai és Petófi kultusza a Vajdaságban. [The Cult of Arany, Jókai and Petófi in Vojvodina.] University of Novi Sad, Teachers' Training Faculty in Hungarian in Subotica. 
Petefi Šandor. 1855. Razorena čarda. [The ruins of the inn.] Preveo Jovan Jovanović Zmaj. Serbski Letopis vol. 91, I: 148-152.

Petefi Šandor. 1946. Izabrane pesme. [Selected Poems.] Novi Sad.

Petrović, Veljko. 1958. Petefi. [Petőfi.] O književnosti i književnicima. Novi Sad. Polit, Vladislava. 1912. Petôfi a szerbeknél. [Petôfi among Serbs.] Novi Sad: Branik nyomda Rt.

Póth István. 1972. Jovan Jovanović Zmaj és a magyar irodalom. [Jovan Jovanović Zmaj in the Hungarian literature] In Szomszédság és közösség. Délszlávmagyar irodalmi kapcsolatok [Neighborhood and Community. South Slavic and Hungarian Literary Relations], ed. Vujicsics D. Sztoján., 369-393. Budapest: Akadémiai Kiadó. 